\title{
Description of some immature stages of Nabis (Tropiconabis) capsiformis (Hemiptera: Nabidae)
}

\section{Descripción de algunos estadios inmaduros de Nabis (Tropiconabis) capsiformis (Hemiptera: Nabidae)}

\author{
Marcela Cornelis ${ }^{1}$, Estela M. Quirán ${ }^{1}$ and María C. Coscarón ${ }^{2 凶}$ \\ ${ }^{1}$ Facultad de Ciencias Exactas y Naturales, Universidad Nacional de La Pampa, Uruguay 151, L6300CLB Santa Rosa, La Pampa, Argentina. \\ ${ }^{2}$ División Entomología, Museo de La Plata, Paseo del Bosque, B1900DNG La Plata, Buenos Aires, Argentina. \\ \mcoscaron@fcnym.unlp.edu.ar
}

\begin{abstract}
Instars III-V of Nabis (Tropiconabis) capsiformis Germar are described and illustrated, based on specimens from La Pampa, Argentina (new record).
\end{abstract}

Key words: Heteroptera, Nabidae, Nabinae, Nabis (Tropiconabis) capsiformis, nymphs.

Resumen. Se describen e ilustran los estadios III-V de Nabis (Tropiconabis) capsiformis German, con base en ejemplares de La Pampa, Argentina (nueva cita).

Palabras clave: Heteroptera, Nabidae, Nabinae, Nabis (Tropiconabis) capsiformis, ninfas.

\section{Introduction}

Nabidae, also known as "damsel bugs", belong to the infraorder Cimicomorpha (Leston et al., 1954) and consist of 31 genera and about 386 species distributed in all the biogeographic regions of the world (Henry, 2009). Nabis belongs to the subfamily Nabinae and has 15 species (Volpi and Coscarón, 2010). Péricart (1987) gave a general contribution to the knowledge of the immature stages of Nabidae. Up to this moment, contributions on instars included 3 species of Nabis: $N$. alternatus Parshley (Taylor, 1949), N. roseipennis Reuter and $N$. rufuluscus Reuter (Mudinger, 1922); several species of Nabicula: N. americolimbata Carayon, N. flavomarginata Scholtz, $N$. limbata Dahlbom, $N$. nigrovittata nearctica Kerzhner, N. propinqua Reuter, N. subcoleoptrata Kirby and N. vanduzeei Kirkaldy (Larivière, 1994); Lasiomerus annulatus Reuter (Larivière, 1993); and Arachnocoris albomaculatus Scott (Myers, 1925) (Nabinae); and Alloeorhynchus trimacula Stein (Cervantes-Peredo, 2004) (Prostenmatinae). Ojeda-Peña (1971) described the nymphs, eggs, and biology of Nabis (Tropiconabis) capsiformis German in Peru. Elvin and Sloderbeck (1984) made a key to the nymphs of 4 species of Nabidae from southeastern USA: N. roseipennis Reuter, $N$. americoferus

Recibido: 23 marzo 2012; aceptado: 07 junio 2012
Carayon, N. (Tropiconabis) capsiformis (Germar), and Hoplistoceslis deceptivus (Harris).

Nabids are generalist predators, feeding on a wide variety of small arthropods (Harris, 1928; Irwin and Shepard, 1980; Jervis, 1990). Many species are numerically important in crops such as soybean, cotton, alfalfa and snuff. The Heteroptera predators of soybean, including Nabis spp., constitute 40 to $89 \%$ of the total insect predators (Irwin and Shepard, 1980). Frascarolo and Nasca (1997) cite $N$. capsiformis as the most common predator in soybeans in the province of Tucumán, Argentina. Additional information in relation to the biology was given by Jessep (1964), Hormchan et al. (1976), Samson and Blood (1979) and Fathipour and Jafari (2008). According to Kerzhner (1983), "pale damsel bugs" are long-winged bugs that fly well, and are the most widespread species in the Nabidae.

Our purpose is to describe the immature stages III-V of $N$. (T.) capsiformis. Instars I and II were not found.

\section{Materials and methods}

The material was collected using a sweep net on May 1, 2010 in Medicago sativa L. (Fabaceae) in Winifreda, La Pampa, Argentina (36¹9’28 .59” S, 6419'50 .84” W). Measurements are in millimeters. Images were taken with a stereoscopic microscope Kyowa $72 \mathrm{X}$ and digital camera Samsung L700. The material was deposited in the Museo de La Plata, Argentina. 


\section{Descriptions}

Instar III (Fig. 1a): body elongate light brown (in some specimens is brown) and setose. Length 2.52-3.11 $($ mean $=2.93 ; n=4)$. Head: length $0.55-0.60$ (mean= 0.58 ), width $0.45-0.48$ (mean $=0.46$ ), light brown at the base of the antennae and clypeus, and eyes and post-ocular region; eye width $0.18-0.22$ (mean $=0.20$ ), vertex width $0.21-0.27$ (mean $=0.24)$. Rostrum: lengths of segment I: $0.15-0.18$ (mean= 0.16 ), II: $0.36-0.42$ $($ mean $=0.38)$, III: $0.36-0.40($ mean $=0.37)$, IV: $0.27-$ 0.30 (mean $=0.28$ ); ratio of segment lengths about 1 : 2.37: 2.31: 1.68. Antenna: lengths of antennal segments I: $0.30-0.42($ mean $=0.39)$, II: $0.45-0.63($ mean $=0.57)$, III: $0.88-0.93$ (mean=0.91), IV: $0.76-0.84($ mean $=0.81)$; ratio of segment about 1: 1.41: 2.11: 1.88. Pronotum brown with a red stripe that runs from the pronotum and anterior half of pteroteca and abdomen length $0.40-0.45$ (mean=0.43), width 0.49-0.51 (mean=0.50). Wing pads length $0.46-0.49$ (mean=0.47) light brown. Abdomen: length $1.95-2.10($ mean $=2.04)$, width $0.66-0.70$ (mean= 0.70). Legs light brown, fore femora: length $0.90-0.96$ $($ mean $=0.94)$, width $0.16-0.18$ (mean $=0.17)$; middle femora: length $0.81-0.85$ (mean $=0.83)$, width $0.10-0.15$ (mean= 0.12); hind femora: length 1.20-1.26 (mean= $1.22)$, width $0.09-0.12($ mean $=0.10)$.

Instar IV (Fig. 1b): body elongate light brown (in some specimens is brown) and setose. Length 3.44-3.70 $($ mean $=3.54 ; \mathrm{n}=3)$. Head: length $0.70-0.77$ (mean= 0.72 ), width $0.52-0.61$ (mean $=0.56)$, buccula + maxillary plate with a red stain, brown at the base of the antennae and clypeus, and eyes and post-ocular region; eye width $0.21-0.28($ mean $=0.24)$, vertex width $0.24-0.28$ (mean= $0.27)$. Rostrum: lengths of segment I: $0.21-0.24$ (mean= $0.22)$, II: $0.45-0.52$ (mean $=0.48)$, III: $0.42-0.52$ (mean= 0.47 ), IV: $0.30-0.33$ (mean $=0.31$ ); ratio of segment lengths about 1: 2.22: 2.18: 1.40. Antenna: lengths of antennal segments I: $0.49-0.56$ (mean $=0.53)$, II: $0.88-$ $0.94($ mean $=0.91)$, III: $1.26-1.29($ mean $=1.28)$, IV: $0.85-0.91$ (mean=0.87); ratio of segment about 1: 1.68 : 2.37: 1.61. Pronotum dark brown with a red stripe that runs from the pronotum and anterior half of pteroteca and abdomen; length $0.45-0.52$ (mean $=0.49$ ), width $0.63-0.70($ mean $=0.66)$. Wing pads length $0.77-0.80$ $($ mean $=0.78)$, brown. Ventral abdomen stripe in the connexival suture, length $2.10-2.38($ mean $=2.22)$, width $0.75-0.84$ (mean= 0.79). Legs light brown, fore femora: length $1.26-1.33($ mean $=1.30)$, width $0.22-0.24$ (mean=
0.23 ) middle femora: length $1.08-1.15$ (mean= 1.12), width $0.14-0.17$ (mean $=0.15)$; hind femora: length $1.70-1.80($ mean $=1.75)$, width $0.10-0.14($ mean $=0.12)$. Instar $V$ (Fig. 1c): body elongate light brown (in some specimens brown) and setose. Length 4.99-5.51 (mean= $5.19 ; \mathrm{n}=7)$. Head: length $0.84-1.00$ (mean $=0.89)$, width $0.65-0.71($ mean $=0.67)$, with $1+1$ red in the post-ocular region (Fig. 1d), buccula + maxillary plate with a red stain (Fig. 1e), brown at the base of the antennae and clypeus, and eyes and post-ocular region; eye width $0.27-0.31$ (mean=0.29), width vertex $0.32-0.37$ (mean= 0.33 ). Rostrum: lengths of segment I: $0.25-0.31$ (mean= $0.28)$, II: $0.69-0.77$ (mean $=0.71)$, III: $0.69-0.75$ (mean= 0.71), IV: $0.37-0.41$ (mean=0.38); ratio of segment lengths about 1: 2.57: 2.53: 1.35. Antenna: lengths of antennal segments I: $0.80-0.86($ mean $=0.82)$, II: $1.25-$ $1.30($ mean $=1.27)$, III: $1.59-1.68($ mean $=1.64)$, IV: $0.79-1.05$ (mean= 0.94); ratio of segment about 1: 1.54: $2: 1.15$. Pronotum darker with a red stripe that runs from the pronotum and anterior half of pteroteca and abdomen; length $0.71-0.80$ (mean= 0.76), width $0.88-1.00$ (mean= 0.96 ). Wing pads length $1.87-1.93$ (mean $=1.90)$, brown. Ventral abdomen stripe in the connexival suture (Fig 1e); length 3.02-3.99 (mean=3.57), width 0.96-1.55 (mean= 1.15). Legs light brown, fore femora: length 1.74-1.81 $($ mean $=1.77)$, width $0.31-0.35($ mean $=0.33)$; middle femora: length 1.57-2.18 (mean=1.80), width $0.19-0.26$ $($ mean $=0.21)$; hind femora: length 2.35-2.64 (mean= 2.44 ), width $0.13-0.19$ (mean=0.15).

\section{Taxonomic summary}

Distribution: Argentina: Buenos Aires (without locality); La Pampa (Winifreda), new record; Mendoza: Potrerillos (32 57’2.67’ S, 69¹2’20.26” W); Misiones (without locality); Salta: Río Bermejo, Salto. Brazil:

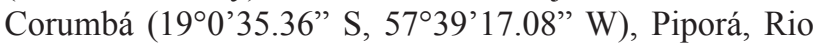

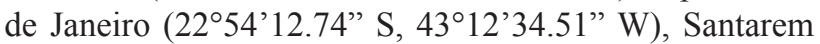
(2²6'21.97' S; 5441'55.45” W). British Guyana. Chile: Arica (18 29'14.56” S, 70¹9'19.77” W). Mexico. Peru:

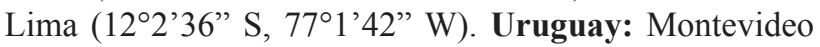
(3449'59.69" S, 569'59.83" W).

Observations: According to Harris (1928), this is a cosmopolitan species occurring in the USA from North Carolina to Texas and southward into South America. In a later publication Harris (1939) gives more information about locality records (which are mentioned above) and states that Potrerillos is in Misiones, but the only Potrerillos found in Argentina is in Mendoza; whereas Arica is in Chile and not in Peru, as mentioned in his publication. 


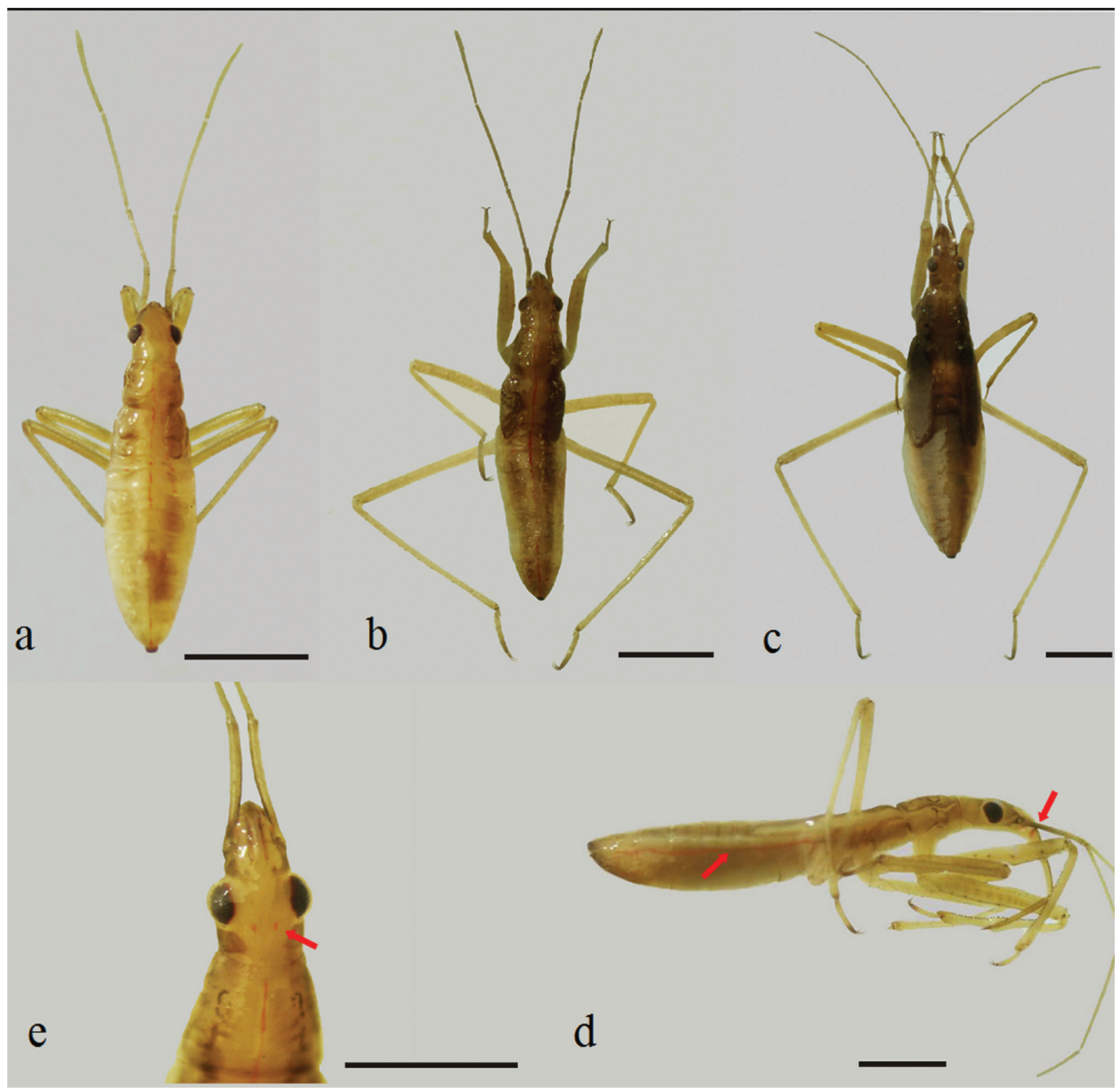

Figure 1. Nabis capsiformis. a), third instar dorsal view; b), fourth instar dorsal view; c), fifth instar dorsal view; d), head with 1+1 red in the post-ocular region, and e), abdomen ventrally with a stripe in the connexival suture. Scale line: $1 \mathrm{~mm}$.

\section{Acknowledgements}

This work was supported by the Consejo Nacional de Investigaciones Científicas y Técnicas (CONICET - Argentina).

\section{Literature cited}

Cervantes-Peredo, L. 2004. Alloeorhynchus trimacula (Stein)
(Heteroptera: Nabidae: Prostemmatinae), a predator of Rhyparochromidae (Lygaeoidea) associated with figs in Mexico. Proceedings of the Entomological Society of Washington 106:346-351.

Elvin, M. K. and P. E. Sloderbeck. 1984. A key to the nymphs of selected species of Nabidae (Hemiptera) in the southeastern USA. Florida Entomologist 67:269-273.

Fathipour, Y. and A. Jafari. 2008. Biology of Nabis capsiformis (Het., Nabidae) preying upon Creontiades pallidus (Het., 
Miridae) in laboratory conditions. Journal of Science and Technology of Agriculture and Natural Resources 12:157166.

Frascarolo, D. and A. J. Nasca. 1997. Estudios biológicos de Nabis capsiformis (Hemiptera: Nabidae). Vedalia 4:49-50.

Harris, H. M. 1928. A monographic study of the hemipterous family Nabidae as it occurs in North America. Entomologica Americana 9:1-97.

Harris, H. M. 1939. Miscelanea sobre Nabidae sudamericanos. Notas del Museo de La Plata, Tomo IV, Zoología 26:368-377.

Henry, T. J. 2009. Biodiversity of Heteroptera. In Insect Biodiversity: science and society, R. Foottit and P. Adler (eds.). Wiley-Blackwell. p. 223-263.

Hormchan, P., M. F. Schuster and L. W. Hepner. 1976. Biology of Tropiconabis capsiformis. Annals of the Entomological Society of America 69:1016-1018.

Irwing, M. E. and M. Shepard. 1980. Sampling predaceous Hemiptera on soybeans. In Sampling methods in soybean entomology, M. Kogan and D. Herzog (eds.). SpringerVerlag, New York. p. 503-531.

Jervis, M. A. 1990. Predation of Lissonota coracinus (Gmelin) (Hymenoptera: Ichneumonidae) by Dolichonabis limbatus (Dahlbom) (Hemiptera: Nabidae). Entomologist's Gazette 41:231-233.

Jessep, I. M. 1964. A note on the feeding habits of Nabis capsiformis Germar. New Zealand Entomologist 3:23.

Kerzhner, I. M. 1983. Airbone Nabis capsiformis (Heteroptera: Nabidae) from the Atlantic, Indian, and Pacific Oceans. International Journal of Entomology 25:273-275.

Larivière, M. 1993. Lasiomerus annulatus (Reuter) (Hemiptera:
Nabidae) in Southern Canada: ecology and phenology, with a description of the last-instar nymph. The Canadian Entomologist 125:513-519.

Larivière, M. 1994. Biodiversity of Nabicula Kirby species (Hemiptera: Nabidae) in Canada: faunistic review, bioecology, biogeography. The Canadian Entomologist 126:327-378.

Leston, D., J. G. Pendergrast and T. R. E. Southwood. 1954. Classification of the terrestrial Heteroptera (Geocorisae). Nature 174:91-92.

Mundinger, F. G. 1922. The life history of 2 species of Nabidae (Hemiptera: Heteroptera). New York State College of Forestry Publication 16:149-167.

Myers, J. G. 1925. Biological notes on Arachnocoris albomaculatus Scott (Hemiptera: Nabidae). Journal of the New York Entomological Society 33:136-146.

Ojeda-Peña, D. 1971. Biología y hábitos de Nabis capsiformis Germar (Hemip.: Nabidae). Sociedad Entomológica de Perú 14:297-303.

Péricart, J. 1987. Hémiptères Nabidae d' Europe Occidentale et du Maghreb. Faune de France 71:1-185.

Samson, P. R. and P. R. B. Blood. 1979. Biology and temperature relationships of Chrysopa sp., Micromus tasmaniae and Nabis capsiformis. Entomologia Experimentalis et Applicata 25:253-259.

Taylor, E. J. 1949. A life history study of Nabis alternatus. Journal of Economic Entomology 42:991.

Volpi, L. N. and M. C. Coscarón. 2010. Catalog of Nabidae (Hemiptera: Heteroptera) for the Neotropical Region. Zootaxa 2513:50-68. 